\title{
Treatment of chronic oroantral fistula with platelet-rich fibrin clot and collagen membrane: a case report
}

This article was published in the following Dove Press journal:

Clinical, Cosmetic and Investigational Dentistry

\author{
Mohammed Jasim \\ Al-Juboori' \\ Mohammed Ahmed \\ Al-Attas ${ }^{2}$ \\ Luiz Carlos Magno Filho \\ 'Department of Periodontology, \\ Al-Rafidain College, Baghdad, Iraq; \\ ${ }^{2}$ Prosthodontic and Dental Implant \\ Department, Riyadh Dental Center, \\ King Saud Medical City, Riyadh, \\ Saudi Arabia; ${ }^{3}$ Department of Oral \\ Implantology, CA Implantes, São Paulo, \\ Brazil
}

\begin{abstract}
An oroantral fistula is a complication of the maxillary posterior teeth that can occur after a tooth extraction that affects the maxillary sinus. Improper management may lead to a persistent fistula, which may become chronic. In this case report, platelet-rich fibrin (PRF) was used with a collagen membrane to close a chronic fistula in a single patient. A flap was raised, the oroantral fistula tract was eliminated, and the opening was closed with a resorbable membrane as a first layer and covered with a PRF clot as a second layer. The flap was closed, and the patient was followed up for suture removal and confirmation of complete soft tissue closure. The postsurgical sign and symptoms of the patient disappeared in the first week; complete tissue healing was detected within 2 weeks, and tissue hypertrophy was observed in the fourth week. The use of PRF may have advantages for soft-tissue healing and for accelerating soft tissue formation by subsequent hypertrophy.
\end{abstract}

Keywords: maxillary sinus, growth factor, soft tissue, flap

\section{Introduction}

Oroantral fistula (OAF) represents a complication of maxillary posterior tooth extraction. Many factors, including lack of a sinus bone floor and direct apposition of the maxillary lining above the maxillary posterior teeth, may increase the incidence of OAF. ${ }^{1}$ Another factor, alveolar bone resorption due to periodontal disease, may halt clot stabilization after tooth extraction. Trauma and traumatic extraction can destroy the bony barrier between the oral cavity and the maxillary sinus. The traditional method for closing the OAF is raising a flap followed by complete closure, with buccal advancement flaps offering advantages over other types of flaps. Buccal flaps provide sufficient access, are easy to achieve, and provide good blood supply and ease of tissue release for complete primary closure. ${ }^{2}$ The main goal of OAF treatment is to achieve complete closure and create a seal between the oral cavity and the maxillary sinus. The drawbacks of flap closure include wound dehiscence, seal breakage, and the need for a second operation. ${ }^{3}$

Many studies have examined the use of different modalities to close the OAF in single, double, and triple layers using different autogenous, allograft, and alloplastic materials and coverage with nonresorbable membranes or titanium mesh. ${ }^{4-8} \mathrm{~A}$ majority of studies have reported the use of resorbable collagen membranes or nonresorbable membranes to separate the graft from the maxillary sinus. ${ }^{9-11}$ Soft tissue enhancement is crucial to assure wound healing and avoid wound breakage complications, which lead to treatment relapse in cases of OAF. One such enhancement method involves the
Correspondence: Mohammed Jasim Al-Juboori

Department of Periodontology, Al-Rafidain University College, Palestine Street, PO Box 46036, Baghdad, Iraq Tel +964 77 |455 955 |

Email doctor_mohamed_2006@yahoo. com 
use of platelet-rich fibrin (PRF), which is a reliable procedure for extracting growth factors from the patient's own blood without the use of additives. ${ }^{12}$ Many growth factors, such as platelet-derived growth factor and transforming growth factor (TGF)- $\beta$, are released from PRF. Growth factors can increase vascularization, do not cause an immunological reaction or pose an infection hazard, and can enhance fibroblast proliferation. ${ }^{13-16}$

With this method, less infection or material rejection will be observed. Many studies have shown the effects of PRF on soft-tissue healing and coagulation, including decreased inflammation and accelerated healing. ${ }^{13-16}$

In our study, we chose the combination of resorbable collagen membranes and PRF clots to close a chronic OAF.

\section{Case report}

A 32-year-old, nonsmoker, systemically healthy man presents to our clinic with the chief complaint of an opening at the extraction site of the upper right first molar (Figure 1). The extraction had been performed more than 3 months previously, and since that time, the patient could not eat properly because the food would exit from his nose. Radiographs were taken, and a diagnosis of chronic OAF was acquired (Figure 2 ). The patient was advised to undergo surgery to close the opening and eliminate the communicating tract between the oral and nasal cavities. A written and informed consent form was obtained from the patient for surgery and publication of the data. Under local anesthesia, a three-sided flap was created; the bone was then exposed, and a large bone defect (greater than $5 \mathrm{~mm}$ ) was found (Figure 3). The soft tissue tract was removed, and bone curettage was performed with a spoon excavator and a round bur drill. Slow-resorption collagen membrane extracted from bovine tendon containing collagen type I (Genoss, Gyeonggi-do, South Korea) was used to cover the bone defect and was fixed in place with nylon suture (Figure 4). PRF was prepared after blood was withdrawn from the patient $(40 \mathrm{~mL})$ and centrifuged for 14 minutes at 1,500 rpm. A PRF clot was isolated from the middle part of the test tube between the red blood corpuscles at the bottom and the platelet-poor plasma at the top; the PRF clot was filtered from the plasma in the form of a thin membrane. The PRF clot was placed above the collagen membrane in two layers (Figure 5). Periosteum scoring was performed with flap release. Primary closure of the tension-free flap was performed with $4 / 0$ nylon suture. Horizontal and vertical mattress suturing was performed with interrupted stitches between layers (Figure 6). The patient was given antibiotics (amoxicillin/clavulanate $625 \mathrm{mg}$, metronidazole $500 \mathrm{mg}$ ) and an analgesic (ibuprofen $400 \mathrm{mg}$ ). The patient was instructed

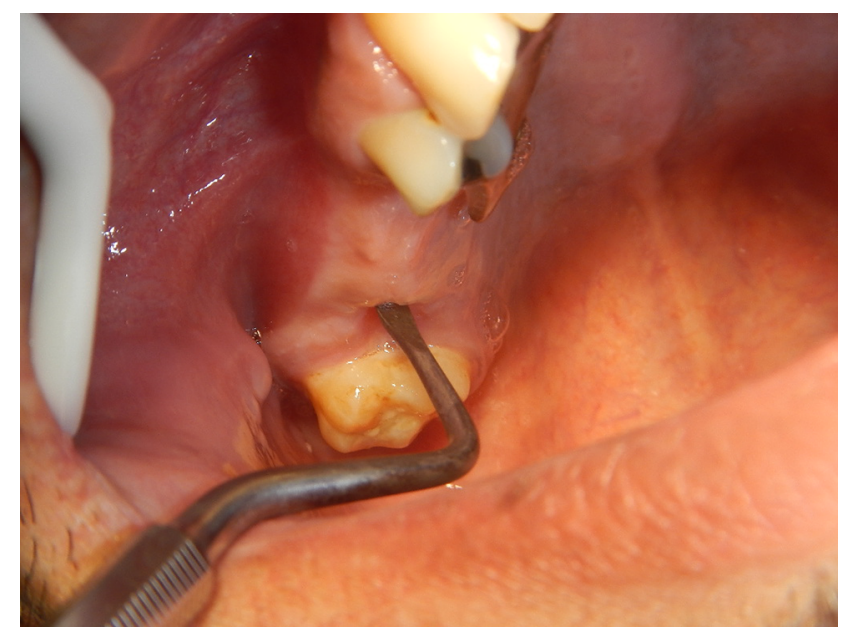

Figure I The fistula is clinically examined with a wide, blunt instrument to detect the site of the opening in relation to the adjacent structure.

Note: Clinically, the opening looks more posterior than that shown on the radiograph.

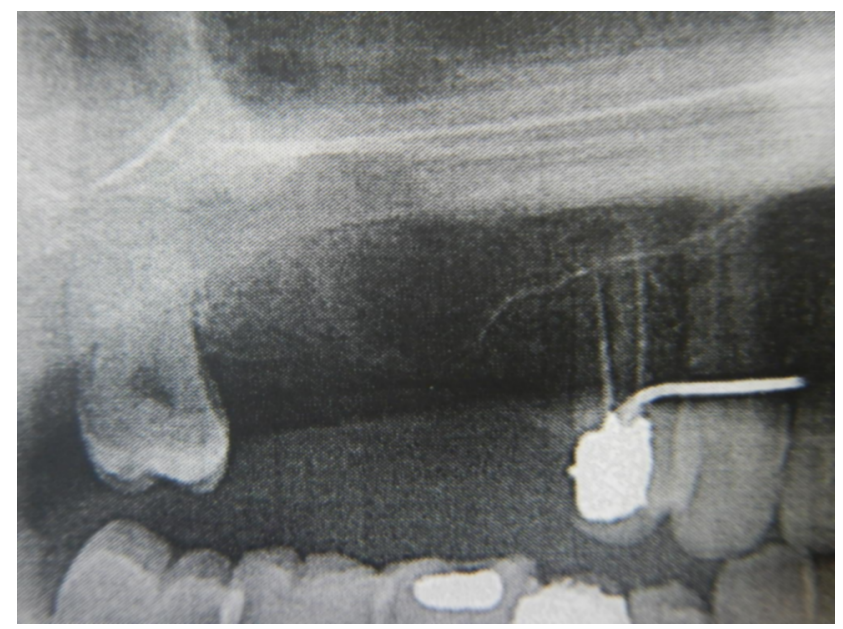

Figure 2 A preoperative panoramic radiograph was taken to detect the site of the fistula and the vertical bone height of the extracted tooth.

Note: The radiograph shows insufficient bone height to support clot formation and that the lining membrane is open directly to the crestal bone.

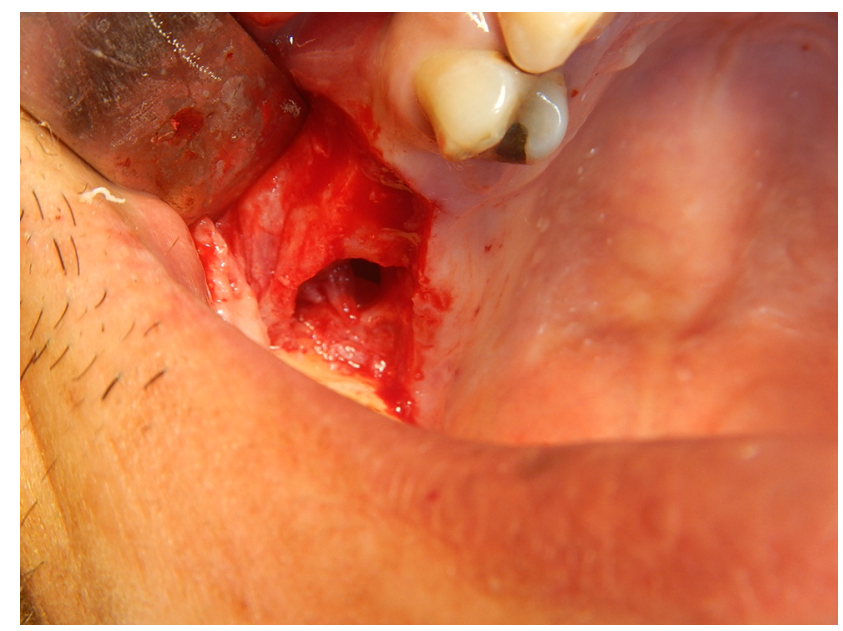

Figure 3 At the site of the first molar, a large bony defect was found after the flap was raised and the bone was exposed.

Note: The defect exhibited a very shallow bone height, which made stabilization of the blood clot difficult. 


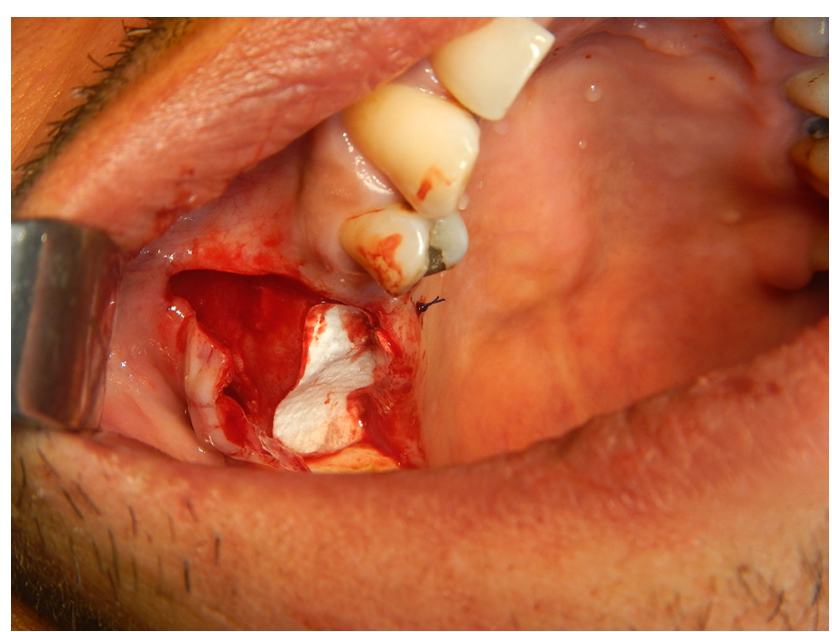

Figure 4 Slowly resorbable collagen membrane was placed as a first layer to close the bone opening and fixed in place with sutures to prevent dislodgment or being aspirated into the sinus.

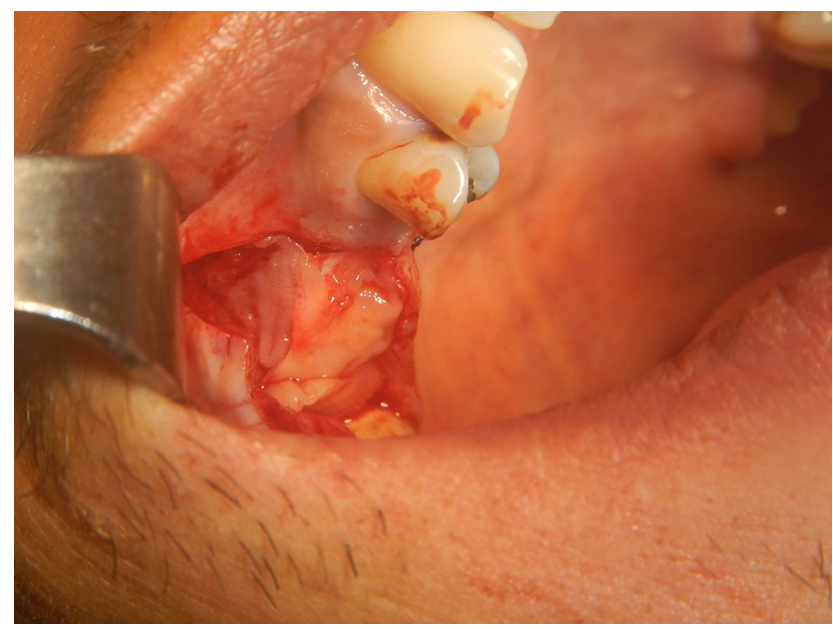

Figure 5 Multiple platelet-rich fibrin clots (more than one clot layered above each other) were placed as a second layer to cover the bony defect and enhance softtissue healing.

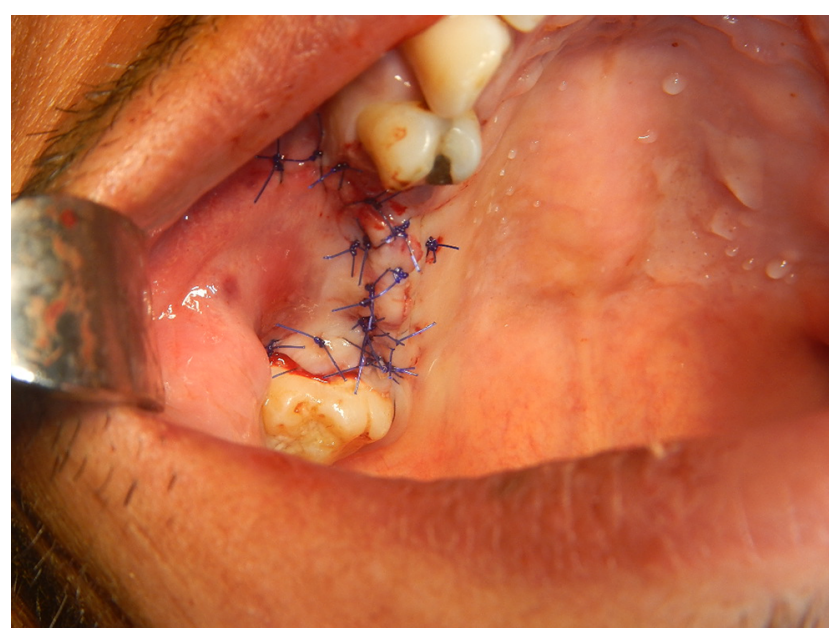

Figure 6 The double-layer flap was closed using mattress and single interrupted sutures with a free-tension flap and eversion to avoid wound dehiscence. not to use straws or blow his nose and to open his mouth during sneezing. The patient was followed up 1 week after surgery, and he reported no pain or discomfort during eating and drinking. At 2 weeks, the wound matured, and signs of inflammation had disappeared; the sutures were partially removed (Figure 7). On the third week, the sutures were completely removed. Gingival overgrowth and an increase in thickness were observed when the patient returned for further follow-up at 6 weeks after surgery (Figure 8).

\section{Discussion}

OAFs have three openings (sinus lining breach, osseous defect, and gingival tissue opening) in different types of tissue that need to be closed and completely isolated from the oral environment and adjacent tissue.

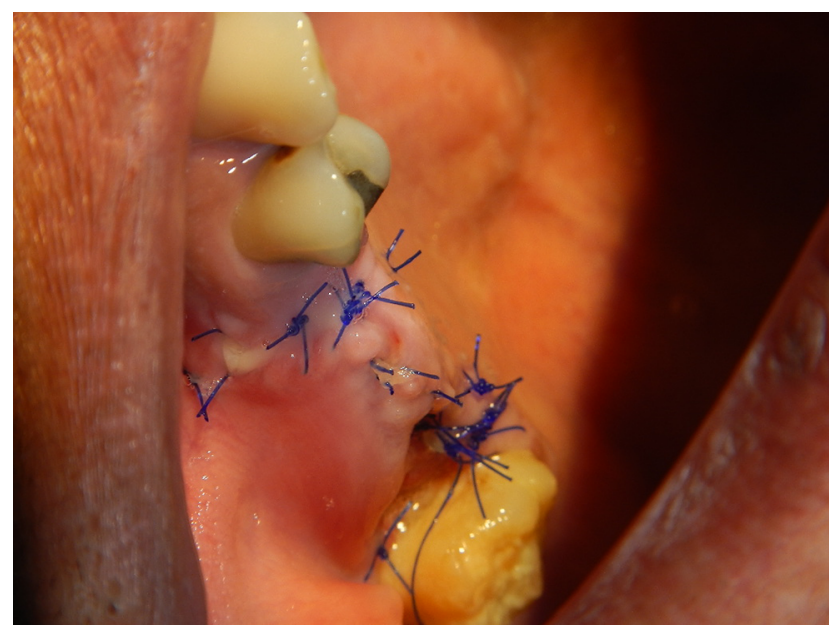

Figure 7 Wound healing was evident after 2 weeks, and the sutures were partially removed.

Note: The fistula was closed, with no communication between the oral and nasal cavities.

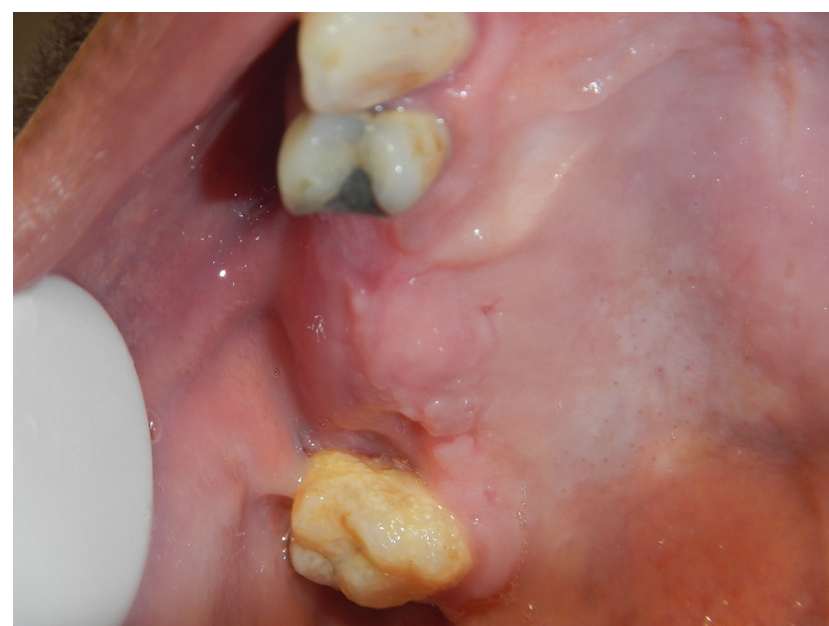

Figure 8 Six weeks after surgery, complete wound healing with obvious hypertrophy of the soft tissue was observed. 
OAFs, if left untreated, may lead to sinus tract formation and chronic sinusitis. Moreover, OAFs can cause morbidity for the patient as a result of pain and the transfer of food and fluid from the oral cavity to the nose. Primary closure of OAFs within 48 hours is associated with success rates of $90 \%-95 \%$, whereas the reported success rate for late secondary closure is $67 \%{ }^{17,18}$

When immediate closure of the OAF does not occur, it is usually because the OAF was not noticed by the surgeon or because the surgeon lacked skill and experience.

Many surgical flap options are available for closure of the OAF, and all of those methods have advantages and disadvantages. Treatment plans vary for each patient and should be determined case by case, taking into account the amount of keratinized tissue, the dentate or edentulous status, and the size and position of the fistulae. ${ }^{19}$ The traditional technique for treatment of an OAF is using a sliding buccal flap to close the opening. However, this technique still has some disadvantages, such as pain, swelling, and reducing the buccal vestibule depth. ${ }^{20}$

Some surgical procedures use autogenous bone or cartilage grafts, which may increase the risk of morbidity to the patient and lengthen the treatment and recovery periods. ${ }^{8,21-23}$ Some studies have reported graft failure following exposure of the graft material or infection of the surgical site. ${ }^{23}$

The use of a buccal fat pad to cover the OAF involves the same degree of invasiveness as the use of a flap from another site, and muscle is cut to release the buccal fat. ${ }^{24-26}$

Our technique involves lower cost, less morbidity, and a shorter healing period than previously reported techniques. Additional advantages of our technique are summarized in Table 1.

In our case, we chose to use the buccal advancement flap because the radiograph showed that the bone opening or defect was anterior to the fistula opening in the soft tissue. Thus, a wide area needed to be exposed to include the bone and soft tissue defect, which could be achieved only with a buccal advancement flap. The drawback of this type of flap is that the vestibule becomes shallower and ends with movable nonkeratinized buccal mucosa. ${ }^{27}$

The use of PRF in dentistry is currently increasing, especially in soft tissue surgery to enhance soft-tissue healing. ${ }^{13-15}$

Gingival tissue hypertrophy was observed after 6 weeks of healing. This observation represents another advantage of the use of PRF in closing the OAF, as the amount of gingival tissue is increased in the area of the bone defect. Gingival hypertrophy reflects the ability of PRF to induce fibroblast cell proliferation. ${ }^{16}$

Of further interest is that no previous research study or clinical trial that used PRF involved the incision or excision of the fistula, unlike studies that did not use PRF. ${ }^{23,28}$
Table I Significant findings in our case, comparing our technique with other OAF closure techniques

\begin{tabular}{|c|c|}
\hline No. & Findings \\
\hline I- & Complete wound closure within 2 weeks \\
\hline 2- & $\begin{array}{l}\text { No excision of the fistula opening from the flap that may } \\
\text { increase the risk of flap defects }\end{array}$ \\
\hline 3- & $\begin{array}{l}\text { Soft tissue hypertrophy and an increase in tissue thickness, } \\
\text { providing more support for wound sealing }\end{array}$ \\
\hline 4- & $\begin{array}{l}\text { Chance of bone formation when a collagen membrane is placed } \\
\text { to prevent soft tissue formation }\end{array}$ \\
\hline 5- & $\begin{array}{l}\text { No second surgery site or donor site needed to close the } \\
\text { opening }\end{array}$ \\
\hline 6- & $\begin{array}{l}\text { Three-layer closure (collagen membrane, PRF clot, and soft } \\
\text { tissue flap) }\end{array}$ \\
\hline 7- & Applicable for large fistula openings \\
\hline 8- & Applicable for chronic fistula (more than 3 months) \\
\hline 9- & $\begin{array}{l}\text { Prevents adhesion of the Schneiderian membrane to the } \\
\text { overlying gingival tissue placing a collagen membrane as a barrier }\end{array}$ \\
\hline 10- & $\begin{array}{l}\text { No need for reentry surgery to remove the membrane or } \\
\text { fixation tools }\end{array}$ \\
\hline II- & Separates the osseous defect from the gingival tissue opening \\
\hline 12- & $\begin{array}{l}\text { Does not increase the size of the surgical site, which would } \\
\text { require an extensive flap to cover }\end{array}$ \\
\hline
\end{tabular}

In the study by Demetoglu et al, ${ }^{12}$ no flap was raised, and only a PRF membrane was used to fix the OAF opening.

The placement of resorbable collagen membrane in our case was to prevent adhesion of the sinus membrane lining to the oral mucosa, which can lead to fusion of the oral mucosa and Schneiderian membrane. ${ }^{10,29}$

Such fusion will prevent future treatments, such as sinus lift and implant placement.

At the same time, the sinus mucosa will have the chance to regenerate and return to its normal morphology. ${ }^{30}$ Another advantage of the placement of collagen membrane is to prevent the proliferation of soft tissue into the osseous defect, which would prevent bone formation and closure of the bony defect.

\section{Conclusion}

In this case, three layers were used to cover the opening of the OAF, and PRF was simultaneously applied to enhance soft-tissue healing. Gingival tissue hypertrophy was observed after 6 weeks of healing.

\section{Disclosure}

The authors report no conflicts of interest in this work.

\section{References}

1. Kim MK, Han W, Kim SG. The use of the buccal fat pad flap for oral reconstruction. Maxillofac Plast Reconstr Surg. 2017;39(1):5.

2. Killey HC, Kay LW. Observations based on the surgical closure of 362 oro-antral fistulas. Int Surg. 1972;57(7):545-549. 
3. Visscher SH, van Roon MR, Sluiter WJ, van Minnen B, Bos RR. Retrospective study on the treatment outcome of surgical closure of oroantral communications. J Oral Maxillofac Surg. 2011;69(12):2956-2961.

4. Kapustecki M, Niedzielska I, Borgiel-Marek H, Różanowski B. Alternative method to treat oroantral communication and fistula with autogenous bone graft and platelet rich fibrin. Med Oral Patol Oral Cir Bucal. 2016;21:e608-e613.

5. Steiner M, Gould AR, Madion DC, Abraham MS, Loeser JG. Metal plates and foils for closure of oroantral fistulae. J Oral Maxillofac Surg. 2008;66(7):1551-1555.

6. Watzak G, Tepper G, Zechner W, Monov G, Busenlechner D, Watzek G. Bony press-fit closure of oro-antral fistulas: a technique for presinus lift repair and secondary closure. J Oral Maxillofac Surg. 2005;63(9):1288-1294.

7. Lee B-K. One-stage operation of large oroantral fistula closure, sinus lifting, and autogenous bone grafting for Dental implant installation. Oral Surg Oral Med Oral Pathol Oral Radiol Endod. 2008;105:707-713.

8. Scattarella A, Ballini A, Grassi FR, et al. Treatment of oroantral fistula with autologous bone graft and application of a non-reabsorbable membrane. Int J Med Sci. 2010;7(5):267-271.

9. Ogunsalu C. A new surgical management for oro-antral communication: the resorbable guided tissue regeneration membrane - bone substitute sandwich technique. West Indian Med J. 2005;54(4):261-263.

10. Ahmed MS, Askar NA. Combined bony closure of oroantral fistula and sinus lift with mandibular bone grafts for subsequent dental implant placement. Oral Surg Oral Med Oral Pathol Oral Radiol Endod. 2011;111(4):e8-e14.

11. Peleg M, Garg AK, Misch CM, Mazor Z. Maxillary sinus and ridge augmentations using a surface-derived autogenous bone graft. J Oral Maxillofac Surg. 2004;62(12):1535-1544.

12. Demetoglu U, Ocak H, Bilge S. Closure of Oroantral Communication With Plasma-Rich Fibrin Membrane. J Craniofac Surg. 2018;29(4):e367-e370.

13. Dohan DM, Choukroun J, Diss A. Platelet-rich fibrin (PRF): a secondgeneration platelet concentrate. Part II: platelet-related biologic features. Oral Surg Oral Med Oral Pathol Oral Radiol Endod. 2006;101:e45-e50.

14. Dohan DM, Choukroun J, Diss A. Platelet-rich fibrin (PRF): a second-generation platelet concentrate. Part I: technological concepts and evolution. Oral Surg Oral Med Oral Pathol Oral Radiol Endod. 2006;101:e37-e44.

15. Choukroun J, Diss A, Simonpieri A. Dohan DM. Platelet-rich fibrin (PRF): a second-generation platelet concentrate. Part IV: clinical effects on tissue healing. Oral Surg Oral Med Oral Pathol Oral Radiol Endod. 2006;101:e56-e60.
16. Dohan DM, Choukroun J, Diss A, et al. Platelet-rich fibrin (PRF): a second-generation platelet concentrate. Part III: leucocyte activation: a new feature for platelet concentrates? Oral Surg Oral Med Oral Pathol Oral Radiol Endod. 2006;101(3):e51-e55.

17. Haanaes HR, Pedersen KN. Treatment of oroantral communication. Int J Oral Surg. 1974;3(3):124-132.

18. Ericson S, Finne K, Persson G. Results of apicoectomy of maxillary canines, premolars and molars with special reference to oroantral communication as a prognostic factor. Int J Oral Surg. 1974;3(6):386-393.

19. Batra H, Jindal G, Kaur S. Evaluation of different treatment modalities for closure of oro-antral communications and formulation of a rational approach. J Maxillofac Oral Surg. 2010;9(1):13-18.

20. Güven O. A clinical study on oroantral fistulae. J Craniomaxillofac Surg. 1998;26(4):267-271.

21. Visscher SH, van Minnen B, Bos RR. Closure of oroantral communications: a review of the literature. J Oral Maxillofac Surg. 2010;68(6):1384-1391.

22. Haas R, Watzak G, Baron M, Tepper G, Mailath G, Watzek G. A preliminary study of monocortical bone grafts for oroantral fistula closure. Oral Surg Oral Med Oral Pathol Oral Radiol Endod. 2003;96(3):263-266.

23. Saleh EA, Issa IA. Closure of large oroantral fistulas using septal cartilage. Otolaryngol Head Neck Surg. 2013;148(6):1048-1050.

24. Yang S, Jee YJ, Ryu DM. Reconstruction of large oroantral defects using a pedicled buccal fat pad. Maxillofac Plast Reconstr Surg. 2018;40(1):7.

25. Hanazawa Y, Itoh K, Mabashi T, Sato K. Closure of oroantral communications using a pedicled buccal fat pad graft. J Oral Maxillofac Surg. 1995;53(7):771-775.

26. George E. Triple-Layered Closure of an Oroantral Fistula: A Case Report. Int J Oral Maxillofac Implants. 2018;33(2):e33-e36.

27. von Wowern N. Closure of oroantral fistula with buccal flap: Rehrmann versus Môczár. Int J Oral Surg. 1982;11(3):156-165.

28. Sayed AA, Khalifa GA, Hassan SA, Mohamed FI. Double-layered closure of chronic oroantral fistulas using a palatal rotational flap and suturing of the sinus membrane perforation: is it a successful technique? J Oral Maxillofac Surg. 2015;73(5):812-818.

29. Lee BK. One-stage operation of large oroantral fistula closure, sinus lifting, and autogenous bone grafting for dental implant installation. Oral Surg Oral Med Oral Pathol Oral Radiol Endod. 2008;105(6):707-713.

30. Baĭdik OD, Logvinovsv ZSG, Sysoliatin PG. Gurin AA. [Structure of maxillary sinus mucous membrane under normal conditions and in odontogenic perforative sinusitis] Struktura verkhnechelyustnoy slizistoy obolochki v normal'nykh usloviyakh i v odontogennyy perforiruyushchiy sinusit. Morfologiia. 2011;139(2):49-54. Russian.
Clinical, Cosmetic and Investigational Dentistry

\section{Publish your work in this journal}

Clinical, Cosmetic and Investigational Dentistry is an international, peer-reviewed, open access, online journal focusing on the latest clinical and experimental research in dentistry with specific emphasis on cosmetic interventions. Innovative developments in dental materials, techniques and devices that improve outcomes and patient satisfac-
Dovepress

tion and preference will be highlighted. The manuscript management system is completely online and includes a very quick and fair peerreview system, which is all easy to use. Visit http://www.dovepress com/testimonials.php to read real quotes from published authors. 